\title{
Inertial control: a novel technique for in-vitro analysis of foot function
}

\author{
Tassos Natsakis ${ }^{1 *}$, Koen Peeters ${ }^{1}$, Fien Burg ${ }^{1}$, Greta Dereymaeker ${ }^{1}$, Jos Vander Sloten ${ }^{1}$, Ilse Jonkers ${ }^{2}$ \\ From 3rd Congress of the International Foot and Ankle Biomechanics Community \\ Sydney, Australia. 11-13 April 2012
}

\section{Background}

In-vitro gait simulations have great potential, allowing a systematic analysis of the foot function. However, it is important that the loading conditions are realistic i.e. physiologic ground reaction forces (GRF). In most experiments, in-vivo measured GRF can be imposed $[1,2]$. However in experimental designs that evaluate the effect of altered muscle forces on foot motion this is more complex; the effect of the altered muscle activity on the loading and kinematics cannot be taken into consideration. Therefore, we investigated the use of a new technique to simulate such cases with realistic loading conditions.

\section{Methods}

Our gait simulator simulates the activation of nine muscles (grouped in six groups), based on electromyography measurements. The forces are applied with pneumatic actuators and are measured by load-cells located between the tendons and the actuators. The set-up is

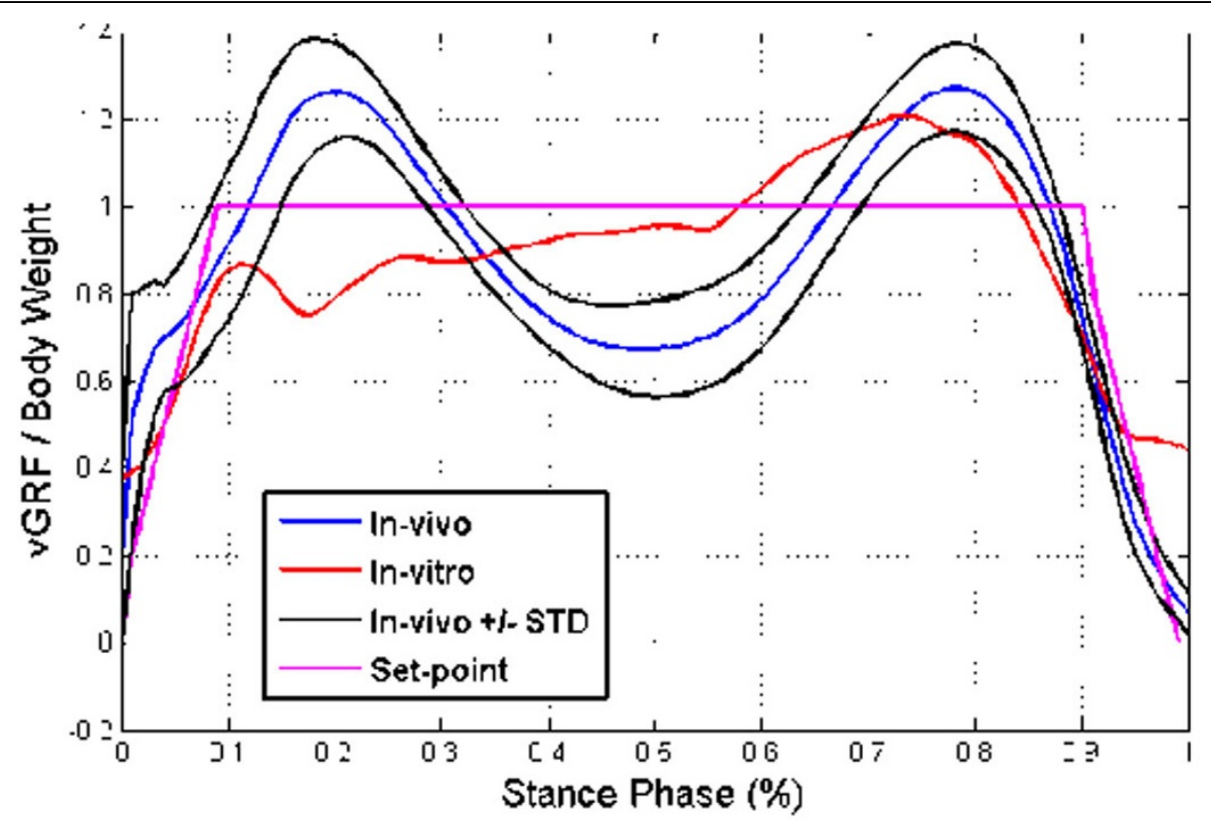

Figure 1 Comparison of the in-vivo and in-vitro measured GRF.

* Correspondence: tassos.natsakis@mech.kuleuven.be

'Mechanical Engineering Department, KU Leuven, Leuven, 3000, Belgium

Full list of author information is available at the end of the article

(C) 2012 Natsakis et al; licensee BioMed Central Ltd. This is an Open Access article distributed under the terms of the Creative Commons 
able to simulate knee motion, using a motor for the horizontal and a platform under the foot for the vertical direction. The stance phase is simulated in 0.8 seconds.

The GRF in human gait is the sum of a static (human weight) and a dynamic part (acceleration of human mass). By applying a constant force on the platform (equal to the assumed weight of the subject), the measured GRF is the sum of the constant force and the force generated from the acceleration of the platform. This way, the kinetics are governed exclusively by the muscle activation.

\section{Results}

Four freshly frozen cadaveric specimens were used, for five measurements each. The in-vitro measured GRF was compared to in-vivo measurements (figure 1) and followed the normal pattern with an RMS error of $22 \%$.

\section{Conclusions}

Using this method, physiological GRF were reconstructed for normal gait, by reconstructing the mechanism that generates GRF. It could be, therefore, used for pathologic gait simulations, since the mechanism is identical.

\section{Acknowledgments}

This work was funded by the Chair Berghmans-Dereymaeker.

\section{Author details}

${ }^{1}$ Mechanical Engineering Department, KU Leuven, Leuven, 3000, Belgium.

${ }^{2}$ Department of Kinesiology, KU Leuven, Leuven, 3000, Belgium.

Published: 10 April 2012

\section{References}

1. Sharkey NA, Hamel AJ: A dynamic cadaver model of the stance phase of gait: performance characteristics and kinetic validation. Clin Biomech (Bristol, Avon) 1998, 13:420-433.

2. Whittaker $E$, Aubin P, Ledoux W: Foot bone kinematics as measured in a cadaveric robotic gait simulator. Gait Posture 2011, 33:645-650.

doi:10.1186/1757-1146-5-S1-042

Cite this article as: Natsakis et al:: Inertial control: a novel technique for in-vitro analysis of foot function. Journal of Foot and Ankle Research 2012 5(Suppl 1):042.

\section{Submit your next manuscript to BioMed Central} and take full advantage of:

- Convenient online submission

- Thorough peer review

- No space constraints or color figure charges

- Immediate publication on acceptance

- Inclusion in PubMed, CAS, Scopus and Google Scholar

- Research which is freely available for redistribution

Submit your manuscript at www.biomedcentral.com/submit
C Biomed Central 